\title{
Clinical Pathology and Histopathology Characteristics of Net-Stressed Striped Bass with "Red Tail"
}

\author{
Craig A. Harms \\ Department of Companion Animal and Special Species Medicine. College of Veterinary Medicine \\ North Carolina State University, Raleigh. North Carolina 27606. USA \\ Craig V. Sulligan \\ Department of Zoology. College of Agriculture and Life Sciences, \\ Campus Box 7617. North Carolina State University, Raleigh. North Carolina 27695. USA \\ RONALD G. HODSON \\ University of North Carolina Sea Grant College Program. \\ Campus Box 8605. North Carolina Slate University. Raleigh. North Carolina 27695. USA

\section{Michael K. STOSKOPF} \\ Department of Companion Animal and Special Species Medicine. College of Veterinary Medicine
}

\begin{abstract}
Simulated artiticial spawning of striped bass Morone saxatilis while undergoing repeated net confinements was used to study the pathogenesis of the hyperemia of the fins and ventrum frequently observed when these fish are handled. Alterations in plasma chemistry that accompanied this external manifestation included markedly reduced osmolality. sodium, and chloride and increased plasma cortisol, total $\mathrm{CO}_{2}$, and anion gap. Hemolysis was visually detectable in plasma from five of six net-stressed fish but not in plasma from the six control fish. Blood smears of treated fish contained spherocytes and crythrocyte fragments and exhibited anisocytosis. Histologically, the caudal tins of treated fish were characterized by mononuclear vasculitis and dilated, congested vasculature occluded with organized thrombi. Splenic architecture of nel-stressed fish was indistinct and contained diffusely coalesced erythrocytes. Conclusive evidence for disseminated intravascular coagulation was not detected by activated clotting time, estimated thrombocyte count. librin degradation products, or histopathology.
\end{abstract}

Wild striped bass Morone saxatilis subjected to capture, repeated handling. and confinement for artificial spawning often develop red fins and ventrum. particularly pronounced in the caudal tin. giving rise to the colloquial descriptive term, "red tail." Pathophysiology of this phenomenon has received little attention in the literature. To characterize selected clinical pathological and histopathological features of this syndrome, we induced "red tail" in domestic striped bass by simulating handling stress associated with artificial spawning (Rees and Harrell 1990). Variables investigated included hematocrit, hemolysis, estimated white cell count, estimated thrombocyte count, fibrin degradation products (FDP), red and white cell mor- phology, activated clotting time (ACT), plasma osmolality. plasma cortisol, plasma electrolytes ( $\mathrm{Na}$, $\mathrm{K}$, and $\mathrm{Cl}$; total carbon dioxide, $\mathrm{TCO}_{2}$; and anion gap. AGAP). aerobic cultures of spleen and caudal kidney, and histopathology of major organs and the caudal fin.

\section{Methods}

Wild female striped bass captured from the mouth of the Roanoke River, North Carolina, and conditioned to captivity for 2 years were held in 38,000-L tanks with flow-through well water as previously described (Hodson and Sullivan 1993). All fish had fully grown post-vitellogenic oocytes at the start of the experiments. Water quality variables noted included temperature at $18^{\circ} \mathrm{C}$, salinity $0 \%$. hardness $350 \mathrm{mg} / \mathrm{L}$ as $\mathrm{CaCO}_{3}$, dissolved oxygen at saturation, and negligible ammonia nitrites and nitrates. Six treatment fish were selected to be confined in 780-L net-pens within the 38,000-L tanks and subjected to $10 \mathrm{~min}$ of net stress two to three times daily for $3 \mathrm{~d}$. Net stress consisted of further confining the six treatment fish within a net $(98 \mathrm{~L})$ held quietly near the water surface. Six control fish were selected at large from the same tank.

At the conclusion of the stress period, fish were anesthetized with quinaldine sulfate at $70-100 \mathrm{mg} /$ L. weighed, measured (total length), and bled from the caudal peduncle. Three milliliters of blood were drawn with no anticoagulant; $2 \mathrm{~mL}$ were placed in an FDP tube and $1 \mathrm{~mL}$ was placed in an ACT tube. An additional $2.5 \mathrm{~mL}$ were drawn in heparinized syringes to evaluate hematocrit, blood 
smears. and plasma chemistry. Activated clotting time tubes were immediately gently inverted. then at $20 \mathrm{~s}$ and every $10 \mathrm{~s}$ thereafter until a solid clot had formed. Fibrin degradation products tubes stood at room temperature $30 \mathrm{~min}$ and were centrifuged for serum collection. Serum was frozen at $-20^{\circ} \mathrm{C}$ for 2 weeks before analysis. Blood smears were made within I min of collection, hematocrit was determined within $30 \mathrm{~min}$, and plasma was harvested within $30 \mathrm{~min}$ and frozen at $-20^{\circ} \mathrm{C}$ before analyses which were completed within 4 weeks. Blood smears were stained with Diff-Quick $^{(1)}$ (American Scientific Products, McGraw Park, Illinois).

All treatment lish and three control fish were cuthanized with an overdose of quinaldine sulfate. Swabs of spleen, liver, and trunk kidney were collected aseptically, plated onto blood agar, and incubated at room temperature. Wet mounts of gill filaments were examined immediately. Tissues tixed in $10 \%$ neutral buffered formalin included caudal fin, heart, swim bladder, cranial kidney, spleen, liver, duodenum, pancreas, gill arch, and ovary. Fixed tissues were processed routinely for paraffin sections and stained with hematoxylin and eosin for histological examination.

Hemolysis was estimated visually from hematocril tubes. Thrombocytes per 100 white blood cells (WBC) were counted on blood smears (Stoskopf 1993). Plasma osmolality was determined on an osmometer (Advanced Micro-Osmometer. Model 3MO, Advanced Instruments, Inc., Needham Heights, Massachusetts). Plasma electrolytes (Na, K. $\mathrm{Cl}, \mathrm{TCO}_{2}$ ) were measured on an automated analyzer (Monarch Plus, Instrumentation Laboratory, Lexing(on. Massachusetts). Anion gap was calculated as follows: $(\mathrm{Na}+\mathrm{K})-\left(\mathrm{Cl}+\mathrm{TCO}_{2}\right)$. Plasma cortisol was determined with an automated fluorescence polarization immunoassay (Abbott Laboratories, North Chicago. Illinois) previously validated for use in striped bass (Noga et al. 1994). Fibrin degradation product measurements were attempted with a commercial kit (Fibrin(ogen) Degradation Products (FDP) Detection Set, Baxter Healthcare Corp. Miami, Florida) with rabbit anti-human fibrinogen as the primary antibody. Measurements of treated tish and control fish were statistically compared by the Wilcoxon signed rank test, except for presence or absence of hemolysis, for which the chi-square test with Yates correction was used.

\section{Results}

Significant changes in clinical pathology were the pronounced decreases in osmolality. $\mathrm{Na}$, and
TABle 1.-Median weight, length. and clinical pathology values of striped hass subjected to net stress on three consecutive days and values for controls. Probahilities list ed were determined from a Wijcoxon signed rank test. except as noted for presence or absence of hemolysis. for which a chi-square lest with Yates correction was used: NS $=$ not significant: $N=6$ for both treatment and control groups.

\begin{tabular}{|c|c|c|c|}
\hline Variable & $\begin{array}{l}\text { Treatment } \\
\text { (quartiles) }\end{array}$ & $\begin{array}{c}\text { Control } \\
\text { (quartiles) }\end{array}$ & $P$ \\
\hline $\begin{array}{l}\text { Weight } \\
\text { (kg) }\end{array}$ & $\begin{array}{c}1.28 \\
(1.11-1.60)\end{array}$ & $\begin{array}{c}1.08 \\
(0.80-1.30)\end{array}$ & NS \\
\hline $\begin{array}{l}\text { Total length } \\
\text { (cm) }\end{array}$ & $\begin{array}{c}54.0 \\
(52.0-57.0)\end{array}$ & $\begin{array}{c}52.0 \\
(44.5-54.5)\end{array}$ & $\mathrm{NSS}$ \\
\hline $\begin{array}{l}\text { Hematexirit } \\
(\%)\end{array}$ & $\begin{array}{c}47.5 \\
(35.0-53.0)\end{array}$ & $\begin{array}{c}42.0 \\
(34.0-47.5)\end{array}$ & NS \\
\hline $\begin{array}{l}\text { ACT: } \\
\text { (s) }\end{array}$ & $\begin{array}{c}80 \\
(5 x-110)\end{array}$ & $\begin{array}{l}4.5 \\
(8.5-120)\end{array}$ & NS \\
\hline $\begin{array}{l}\text { Thrombexyles } \\
I(x) W B C^{b /}\end{array}$ & $\begin{array}{l}(0) \\
(24-1(49.75)\end{array}$ & $\begin{array}{l}92 \\
(04-1+2)\end{array}$ & NS \\
\hline $\begin{array}{l}\text { Cortisol } \\
(\mu \mathrm{g} / \mathrm{dL})\end{array}$ & $\begin{array}{c}81.43 \\
(72.58-1(14.07)\end{array}$ & $\begin{array}{c}24.38 \\
(13.16-27.21)\end{array}$ & $=0.01$ \\
\hline $\begin{array}{l}\text { Osmolality } \\
\text { (mOsm) }\end{array}$ & $\begin{array}{l}291 \\
(270-.307)\end{array}$ & $\begin{array}{c}344 \\
(3.34-357)\end{array}$ & $=0.01$ \\
\hline $\begin{array}{l}\mathrm{Na} \\
(\mathrm{mmol} / \mathrm{l} .)\end{array}$ & $\begin{array}{l}116 \\
(1107-129.5)\end{array}$ & $\begin{array}{l}168 \\
(164 t-168.5)\end{array}$ & $<0.01]$ \\
\hline$K_{\text {(mnol/L) }}$ & $\begin{array}{c}4.2 \\
(2.8-4.4)\end{array}$ & $\begin{array}{c}2.7 \\
(2.3-3.2)\end{array}$ & NS \\
\hline $\begin{array}{l}\text { Cl } \\
(\mathrm{mmol} / \mathrm{L})\end{array}$ & $\begin{array}{c}60.5 \\
(54.5-71.25)\end{array}$ & $\begin{array}{c}140.0 \\
(139.8-141.5)\end{array}$ & $<0.01$ \\
\hline $\begin{array}{l}\text { Total } \mathrm{CO}_{2} \\
\text { (m)mol/h) }\end{array}$ & $\begin{array}{c}18.0 \\
(14.2-22.0)\end{array}$ & $\begin{array}{c}11.0 \\
(9 .(2-13.2)\end{array}$ & $\because 0.05$ \\
\hline $\begin{array}{l}\text { AGAPC } \\
\text { (mmol/L) }\end{array}$ & $\begin{array}{c}42.0 \\
(34.0-4 \times .5)\end{array}$ & $\begin{array}{c}17.2 \\
(15.8-20.6)\end{array}$ & $\because 0,01$ \\
\hline $\begin{array}{l}\text { Hemolysis } \\
\text { (number of } \\
\text { fish) }\end{array}$ & 5 & 0 & $0.015^{d}$ \\
\hline
\end{tabular}

activated clonting time.

b White blood cells.

'Anion gap.

"Chi-square test.

$\mathrm{Cl}$ and increases in cortisol, $\mathrm{TCO}_{2}$. and $\mathrm{AGAP}$ in treatment fish (Table 1). Although not statistically significant. there was a decreasing trend in thrombocyte count, with four of six treatment fish having less than 70 thrombocytes/100 WBC, and five of six control fish with more than 70 . All treatment fish developed moderate to severe hyperemia of fins and ventral skin. One of six treatment fish had Saprolegnia sp. growth around the head, and two of six had unidentified mesenteric nematodes. One treatment fish yielded a pure culture of Pseudomonas vesicularis from the spleen. All treatment and control fish examined had pale livers, possibly a result of the manufactured diets fed to the captive brood stock (Brown et al. 1993). Anisocytosis. spherocytes. and red blood cell fragments were common on blood smears from treatment tish (tive of six) but absent from controls. Lymphocytes 


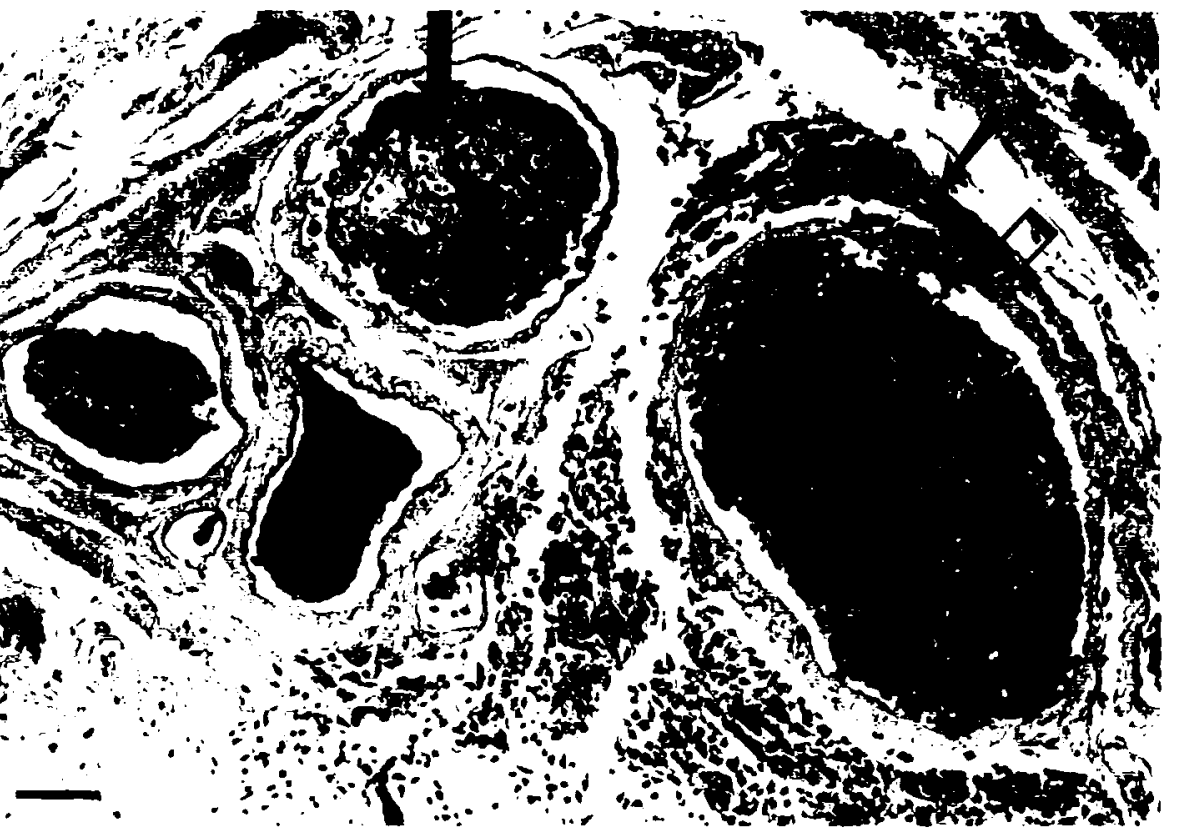

Figure 1. - Caudal tin cross section of nel-stressed striped bass. Vasculature is dilated. congested. and occluded with organized thrombi (large solid arrow) consisting of coalesced thrombocytes and erythrocytes. Vasculitis is indicated by the disrupted endothelium (open arrow) and mononuclear perivascular inflammation (llared solid arrow). Bar $=26 \mu \mathrm{m}$.

from treatment fish were reactive, with deep blue cytoplasm and pscudopodia. whereas in control fish they were quiescent.

The caudal fin vasculature of all stressed tish was dilated, congested. and occluded with organized thrombi composed of thrombocyles and coalesced erythrocytes (Figure 1). Mononuclear vasculitis with different degrees of intimal hyperplasia were present in the caudal tins of tive of six stressed fish. with interstitial perivascular hemorrhage in the single remaining fish. The caudal fin blood vessels of control fish infrequently contained erythrocytes in the plane of section, and vascular endothelial cells were intact (Figure 2). Hepatic congestion was present in one treatment fish, splenic congestion in two treatment fish. and interrenal congestion and hemorrhage in one treatment fish. Vascular changes were not noted in sther organs of treatment fish. and none were noted in control fish. The spleen of stressed tish contained diffusely coalesced red cells and indistinct melanomacrophage centers with macrophages frequently spreading from the centers into the surrounding stroma. Splenic architecture of the stressed fish was indistinct. In contrast. the spleen of control fish contained normal distinct red cells and more discreet melanomacrophage centers, with clearly distinguishable areas of red pulp and white pulp. Hepatocytes of both ireatment and control fish had vacuolated cytoplasm consistent with lipid storage. helieved to be of nutritional origin. Gills of both treatment fish and control fish had histologic evidence of epitheliocystis (three of six treatment fish. one of three controls), trichodinids (five of six treatment tish. two of three controls) and telangiectasia (two of six treatment tish, one of three controls).

\section{Discussion}

Changes in fish blood clotting systems have been reported in response to environmental stressors (confinement. agitation. poor water quality. decompression. and hook and line) (Casillas and Smith 1977: Woodward et al. 1979: van Vliet et al. 1985) and infectious agents (Miller and Levin 1984: Macc Millan et al. 1989: Salte el al. 1991). Disseminated intravascular coagulation (DIC) has been demonstrated in farmed Atlantic salmon Salmo salar with "Hitra disease" (Salte et al. 1987: Salte and Norberg 1991). Although we were unable to provide conclusive evidence of DIC in striped bass with "red tail" by the relatively insensitive methods of ACT. thrombocyte counts. or histopathology. intravascular coagulation local- 


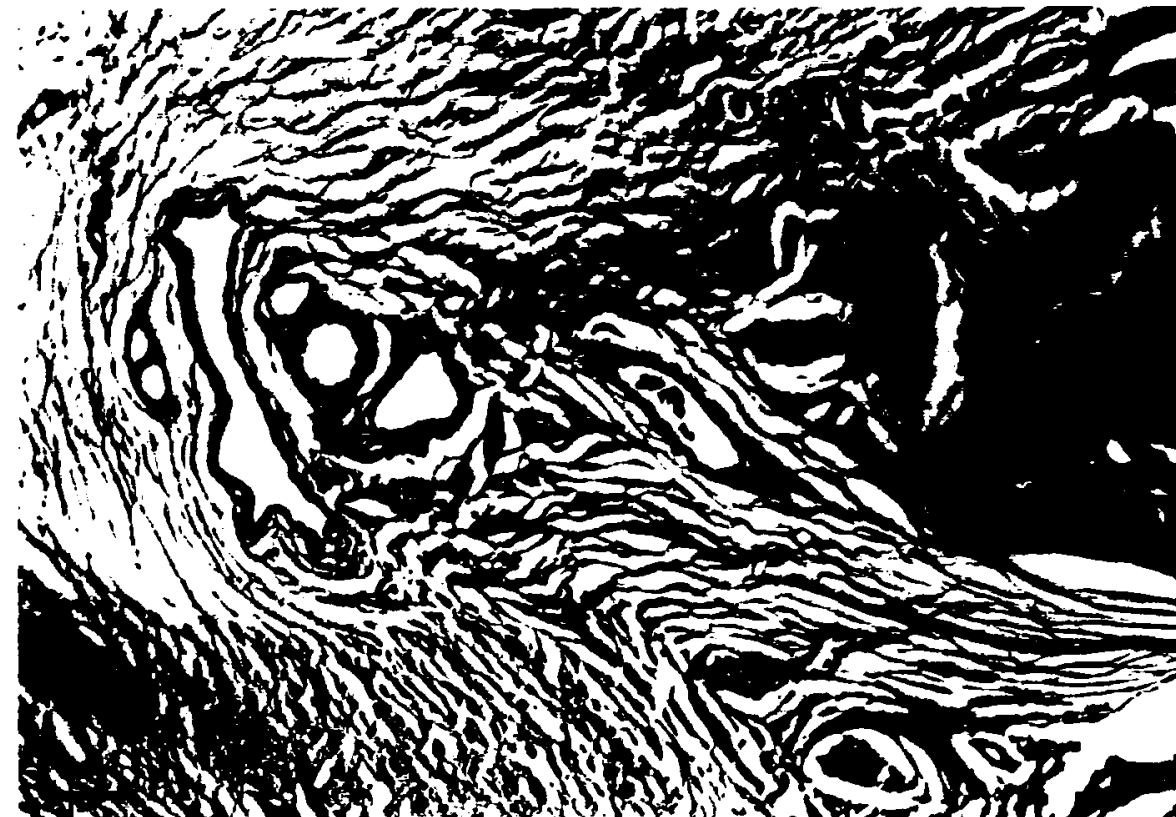

Figure 2. Caudal in cross section of control striped hass. Vasculature is not dilated. is virtually devoid of circulating cells, and lacks any indication of vasculitis. Dark object at right is a partial cross section of al lin ray. Bar = $31 \mu \mathrm{m}$.

ized to the fins was detected histologically. Fibrin degradation product measurements, which are useful indicators of DIC in mammalian species, were unsuccessful because of an apparent lack of crossreactivity of the assay's rabbit anti-human fibrinogen antibody with striped bass fibrinogen. Other measures of clotting function re.g.. prothrombin time. partial thromboplastin time, thrombin time) were not attempted. Decreases in thrombocyte counts were not statistically significant: however. it is possible that the threshold of a consumptive coagulopathy had not been attained in all treatment fish within the allotted time.

Plasma cortisol increases in response to confinement have been previously documented for striped bass (Noga et al. 1994). Control of ion exchange across the gills involves a complex interaction of acid-base and electrolyte balance with neuroendocrine effectors, including cortisol (Evans 1975; McDonald et al. 1989: Perry and Laurent 1989); stress-induced perturbations in the system lead to osmoregulatory dysfunction (Harrell 1992). Salt has been shown to mitigate plasma corticosteroid and chloride responses in striped bass during transport (Harrell 1992). Increasing salinity to reduce osmotic electrolyte loss by the fish is the rationale behind this generally successful treatment of "red tail." Hemolysis and altered red cell morphology observed in the present study were likely secondary to markedly lowered plasma osmolality. Release of intracellular proteins and electrolytes from lysed red ceils could play a mitigating role in maintaining plasma osmotic pressure in the face of $\mathrm{Na}$ and $\mathrm{Cl}$ efflux.

Histologically. the red color of tins and skin in striped bass with "red tail" clearly results from vascular congestion. localized intravascular thrombi. and occasional perivascular hemorrhage. The dilatation of microvasculature. along with thrombus formation. may indicate sluggish peripheral blood flow suggestive of shock. Blood stasis causes local anoxemia. hypercapnia, and acidosis. which can cause endothelial injury (Slappendel 1989). Immunosuppression in affected striped bass was suggested by saprolegniasis in onc fish, and the culture of Psciudomonas resicularis from another, but sepsis was not a consistent feature of the red tail syndrome. The spleen appeared highly active in clearing damaged red cells from circulation. Hemolysis for any cause (most likely osmotic in this casc) can lead to intravascular coagulation because of release of thromboplastic materials (Slappendel 1989). Thrombus formation in peripheral microvasculature may have been promoted by blood stasis, endothelial damage. and hemolysis. Although thrombus for- 
mation was localized rather than disseminated and crude measures of clotting function (ACT, estimated thrombocyte count) did not provide evidence of DIC. conditions favored its development had they continued.

Although reddened fins are classically considered indicators of septic or stressed fish (Gratzek 1992). the pathophysiology has not been thoroughly investigated. Peripheral erythema. particularly of the fins, is considered one of the most common pathological conditions of the circulatory system resulting from toxic or septic insults (Fergeson 1989). yet histologic descriptions are rare. This report supplies some preliminary observations of the phenomenon in striped hass stressed by frequent handling.

\section{Acknowledgments}

We thank the Pamlico Aquaculture Field Laboratory staff and students for their assistance, $L$. Khoo and E. Noga for corroborating fin histopathology interpretation. J. Wright for photomicrography assistance, and T. Mashima for review of the manuscript.

\section{References}

Brown, P. B., M. E. Griffin, and M. Randall White. 1993. Fxperimental and practical diet evaluations with juvenile hybrid striped bass. Journal of the World Aquaculture Society 24:80-89.

Casillas, F., and L. S. Smith. 1977. Elfect of stress on blood coagulation and haematology in rainbow trout (Salmo gairdneri). Journal of Fish Biology 10:481491.

Evans. D. H. 1975. Ionic exchange mechanisms in fish gills. Comparative Biochemistry and Physiology S1 A:491-495.

Fergeson, H. W. 1989. Systemic pathology of tish. Jowa State University Press, Ames.

Gralzek. J. B. 1992. Aquariology: the science of tish health management. Tetra Press. Moor Plains. New Jersey.

Harrell. R. M. 1992. Stress mitigation by use of salt and ancsthetic for wild striped hass captured for brood stock. Progressive Fish-Culturist 54:228233.

Hodson. R. G.. and C. V. Sullivan. 1993. Induced maturation and spawning of domestic and wild striped hass, Morone saxatilis (Walbaum), broodslock with implanted GnRH analogue and injected hCG. Aquaculture and Fisheries Management 24:389-398.

MacMillan. J. R.. D. Mulcahy. and M. L. Landolt. 1989. Cytopathology and coagulopathy associated with viral erythrocylic necrosis in chum salmon. Journal of Aquatic Animal Health 1:255-262.

McDonald, D. G.. Y. Tang. and R. G. Boutilier. 1989. Acid and ion transfer across the gills of fish: mech anisms and regulation. Canadian Journal of Zoology 67:3046-3054.

Miller. T. K., and J. Levin. 1984. The effects of multiple injections of bacterial endotoxin on blood coagulation in the toadish. Opsanus tau. Biological Bulletin (Woods Hole) 166:189-205.

Noga, E. J.. J. H. Kerhy, W. King. D. P. Aucoun, and F. Gieshrecht. 1994. Quantitative comparison of the stress response of striped hass (Morome scxatilis) and hybrid striped bass (Morone saxatilis $\times$ Moromt chrysops and Morone saxatilis $\times$ Morome ameri (ana). American Journal of Veicrinary Rescarch 5.5: $405-409$.

Perry, S. F. and P. laurent. 1989. Adaptational responses of rainhow trout to lowered externat $\mathrm{NaCl}$ concentration: contribution of the branchial chloride cell. Journal of Experimental Bulogy 147:147-168.

Rees. R. A.. and R. M. Harrell. 1990. Artiticial spawning and fry production of striped bass and hybrids. Pages 43-72 in R. M. Harrell. J. H. Kerby and R. V. Minton. editors. Culture and propagation ol striped bass and its hybrids. American lisheries $\mathrm{Su}$ ciety. Southern Division. Suriped Bass Commitles. Bethesda, Maryland.

Salte, R.. P. Natstad, and T. Asgard. 1987. Disseminaled intravascular coagulation in "Hitra disease" (hemorrhagic syndrome) in farmed Atlantic salmon. Vet. erinary Pathology 24:378-385.

Salte. R., and K. Norherg. 1991. Disseminated intravascular coagulation in farmed Atlantic salmon. Salmo salar $\mathrm{I}$ : evidence of consumptive coagulopathy. Journal of Fish Diseases 14:475-480.

Salte, R., K. Norberg, and O. R. Odegaard. 1991. Do extracellular products of Aeromemess salmonicida induce thrombosis by entering the tish coagulation system at factor $X$ ? Journal of Fi:ih Discases 14: $40 !-406$.

Slappendel, R. J. 1989. Disseminated intravascular (o)agulation. Pages 45 I-464 in R. W. Kirk, edilor. Current veterinary therapy $X$ : small animal practice. Saunders, Philadelphia.

Stoskopf, M. K. 1993. Clinical pathology. Pagex 113131 in M. K. Sloskopf. Fish medicine. Saunders. Philadelphia.

van Vliet, K. J., G. I. Smit. J. J. Pieterse, J. J. Schoonbee, and J. H. J. Van Vuren. 1985. A thromboelastographic study of the effect of stress on the blood coagulation in Cyprinas corpio (Cyprinidate) and Oreochromis mosiambicus (Cichlidac). Comparative Biochemistry and Physiology 82A:23-27.

Woodward. J. J.. E. Casillas, L. S. Smith. and B. C. D'Aoust. 1979. Rapid decompression stress accelerates fibrinolysis in tingerling salmon. Journal of the Fisheries Research Bourd of Canada 36:592594. 